\title{
Taking Onboard the Issue of Disembarkation
}

\section{The Mediterranean Need for Responsibility-Sharing after the Malta Declaration}

\author{
Jaspervan Berckel Smit \\ LL.M. Public International Law, Amsterdam Law School, \\ University of Amsterdam, Amsterdam, The Netherlands \\ j.w.j.vanberckelsmit@uva.nl
}

\begin{abstract}
Disembarkation of rescued refugees is increasingly denied by Mediterranean States, as disembarkation triggers obligations of refugee reception in the absence of a distribution mechanism. This article assesses the international law of the sea to answer the question why a distributive mechanism is needed to provide for a predictable solution for disembarkation of rescued refugees in the Mediterranean. It concludes that, due to States' shared obligation to allow disembarkation of seaborne refugees and uncertainties over ill-defined essential concepts and responsibilities, States enjoy much discretion to securitize maritime migration. It frustrates search and rescue (SAR). A successful way to reestablish the integrity and effectiveness of the SAR regime is to create an effective and foreseeable relocation mechanism. Finally, this article's critical analysis of the Malta declaration - which failed to resolve the stalemate in the central Mediterraneanprovides for valuable lessons towards a new system of responsibility-sharing in Europe.
\end{abstract}

\section{Keywords}

disembarkation - rescued refugees - search and rescue - central Mediterranean relocation scheme - shared responsibility - Malta declaration

\section{Introduction}

Navigation at sea is inherently perilous. Especially when unsafe conditions occur aboard, due to an unseaworthy vessel, the dangerous characteristics of 
the sea are likely to cause a threatening situation for crew and passengers. The latter is a reality faced by numerous refugees trying to cross the Mediterranean Sea in oftentimes rickety vessels. ${ }^{1}$

Crossing the central part of the Mediterranean became increasingly dangerous after the EU Member States terminated operation 'Mare Nostrum'predominantly aimed at search and rescue (SAR) of persons in distress at sea $^{2}$ - and replaced it by operation 'Triton' operated by FRONTEX (the Border and Coast Guard Agency of the EU) ${ }^{3}$ - primarily designed to strengthen border surveillance and control. ${ }^{4}$ Triton's successor 'Themis' preserved border control as foremost objective. ${ }^{5}$ The change of operations thus caused a humanitarian gap. ${ }^{6}$ In the absence of state-led rescue programs, NGOs play a lifesaving role filling this gap, ${ }^{7}$ as demonstrated by the statistics over the

1 EU Observer, EU Commission spins half-truth on 'unsafe' refugee boats (7 Dec 2018), https://euobserver.com/migration/143637, accessed 12 Sept 2019; Іом, Missing Migrants Project, Geneva: Iом, https://missingmigrants.iom.int/region/mediterranean, accessed 16 Nov 2019.

2 This naval and air operation was a reaction by the Italian Government to the growing migration influx during 2013. See http://www.marina.difesa.it/EN/operations/Pagine/Mare Nostrum.aspx, accessed 1o Aug 2019.

3 European Commission, Factsheet, EU Operations in the Mediterranean Sea (4 Oct 2016).

4 Andersson, R. (2014). Illegality, Inc.: Clandestine Migration and the Business of Bordering Europe. University of California Press, Oakland; Gammeltoft-Hansen, T. and Nyberg Sorensen, N. (2013). The Migration Industry: The Commercialization of International Migration. London: Routledge.

5 See Vosyliūtè, L. (2018). Is saving lives still a priority for the EU?, Reconnecting Europe Blog, https://eu.boell.org/en/2018/o4/19/saving-lives-sea-still-priority-eu, accessed 17 April 2020.

6 European Commission President Juncker, later acknowledged in a public speech: "it was a serious mistake to bring the Mare Nostrum operation to an end. It costs human lives." European Commission, Speech by President Jean-Claude Juncker in the European Parliament debate on the conclusions of the Special European Council on 23 April 2015: 'Tackling the Migration Crisis' SPEECH/15/4896, (29 April 2015).

7 Arsenijevic, J., Manzi, M. and Zachariah, R. (2017). Are dedicated and proactive search and rescue operations a 'pull factor' for migration and do they deteriorate maritime safety in the Central Mediterranean?, http://searchandrescue.msf.org/assets/uploads/files/170831-\%20 Report_Analysis_SAR_Final.pdf, accessed 25 May 2020; Steinhilper, E. and Gruijters, R. (2017). Border Deaths in the Mediterranean: What We Can Learn from the Latest Data, https://www .law.ox.ac.uk/research-subject-groups/centre-criminology/centreborder-criminologies/ blog/2017/o3/border-deaths, accessed 25 May 2020; Heller, C. and Pezzani, L. (2017). Blaming the Rescuers: Report. Forensic Oceanography; Médecins Sans Frontières (MSF) Issue Brief (2017). Humanitarian NGOs conducting Search and Rescue Operations at Sea: A 'pull factor'?, http://searchandrescue.msf.org/assets/uploads/files/170831_Analysis_SAR_Issue_Brief _Final.pdf, accessed 25 May 2020. 
years. ${ }^{8}$ However, their increased humanitarian activism was not appreciated by coastal States who argue that the towering death toll in the Mediterranean Basin is caused by a growing number of rescue services that serve as 'pull factor' for illegal migration. ${ }^{9}$ Although there is no empirical evidence that sustains this claim, ${ }^{10}$ this rationale has been used by EU Member States to criminalize rescuing NGOs through seizure of vessels ${ }^{11}$ and the prosecution of rescuers. ${ }^{12}$ Furthermore, coastal States have deregistered NGO rescue vessels ${ }^{13}$ and have increasingly proven to be reluctant to allow disembarkation of seaborne refugees, rescued by these ships. ${ }^{14}$

The hostile position of EU Member States can be explained by the absence of a relocation mechanism to share the responsibility for asylum seekers and

8 See 2016: https://www.guardiacostiera.gov.it/attivita/Documents/attivita-sar-immig razione-2016/ANNUALE\%2oITA.pdf; 2017: https:/www.guardiacostiera.gov.it/attivita/ Documents/attivita-sar-immigrazione-2017/annuale\%202017\%2oita.pdf; 2018: https:// www.guardiacostiera.gov.it/attivita/Documents/attivita-sar-immigrazione-2018/ Annuale\%2O2018\%20ITA.pdf, accessed 19 Aug 2020; MSF Issue Brief 2017, see previous fn. See Del Valle, H. (2016). Search and Rescue in the Mediterranean Sea: Negotiating Political Differences. Refugee Survey Quarterly 35(2), pp. 22-40; Toaldo, M. (2015). Libya's Migrant-smuggling Highway: Lessons for Europe. European Council on Foreign Relations; Cusumano, E. (2017). Emptying the sea with a spoon? Non-governmental providers of migrants search and rescue in the Mediterranean. Marine Policy 75, pp. 91-98.

10 Cusumano, E. and Villa, M. (2019). Sea Rescue NGOs: a Pull Factor of Irregular Migration?, Florence: European University Institute, Robert Schuman Centre for Advanced Studies, Migration Policy Centre, 2019/22 (Nov 2019).

11 Heller and Pezzani (2017), supra fn. 7; see overview criminalization of rescue NGOS, in FRA (2019). 2019 update-NGO ships involved in search and rescue in the Mediterranean and criminal investigations (19 June 2019), https://fra.europa.eu/en/ publication/2019/2019-update-ngo-ships-involved-search-and-rescue-mediterranean -and-criminal\#TabPubOverview, accessed 6 May 2020; see for general response, Conference of INGOs of the Council of Europe (2020). Guidelines on protecting NGO work in support of refugees and other migrants, Expert Council on NGO law CONF/EXP(2020) (3 May 2020).

12 The Guardian, Rescue ship captain arrested for breaking Italian blockade (29 June 2019). https://www.theguardian.com/world/2019/jun/29/sea-watch-captain-carola-rackete -arrested-italian-blockade, accessed 7 Jan 2020; Human Rights Watch (HRW) (2018). Greece: Rescuers at Sea Face Baseless Accusations (5 November 2018), https://www .hrw.org/news/2018/11/o5/greece-rescuers-sea-face-baseless-accusations, accessed 13 Sept 2019.

13 See concise overview in Schatz, V.J. and Endemann, F. (2019). The Vatican City State's Refusal to Grant its Flag to Search and Rescue Vessels of NGOs Operating in the Mediterranean. The Italian Yearbook of International Law 28(1), pp 97-109, at 99-101.

14 Fine, S. (2019). All at Sea: Europe's Crisis of Solidarity on Migration. ECFr Policy Brief, London: European Council on Foreign Relations. 
refugees ${ }^{15}$ among Member States. In the absence of such a mechanism, the anti-immigration policy of European 'frontline states' such as Greece and Italy, is to some extent understandable. ${ }^{16}$ The Dublin III Regulation ${ }^{17}$ — core of the EU asylum acquis - suffers from structural shortcomings regarding an effective distribution of responsibilities, ${ }^{18}$ as a result of which Italy and Greece received respectively 182,535 and 59,610 applications for international protection in 2015 and 2016. ${ }^{19}$ Consequently, a reformation process of Dublin III has been set in motion in $2016,{ }^{20}$ with a view to streamlining and supplementing the current rules with a 'corrective allocation mechanism. ${ }^{21}$ However, the European Council has been unable to reach consensus on the reform, necessitating the Commission to withdraw its initial proposal. ${ }^{22}$ Moreover, besides the delaying Dublin reform, EU Member States were unable to meet the

15 Remark that migration by sea concerns mixed flows. A migrant should receive international protection, unless determined not to be a refugee.

16 See for discussion on burden sharing, Klug, A. (2014). Strengthening the Protection of Migrants and Refugees in Distress at Sea through International Cooperation and Burden-Sharing. International Journal of Refugee Law 26(1), pp. 48-64.

17 Council of the European Union, Regulation (EU) No 604/2013 of the European Parliament and of the Council of 26 June 2013 establishing the criteria and mechanisms for determining the Member State responsible for examining an application for international protection lodged in one of the Member States by a third-country national or a stateless person (recast), (29 June 2013), OJ L. 180/31-180/59; 29 June 2013.

18 A deficiency that was affirmed by the European Commission, see Evaluation of the Dublin III Regulation, final report. (2015). DG Migration and Home Affairs; see also European Commission (2016). Сом(2016) 197 final. Towards a reform of the Common European Asylum System and enhancing legal avenues to Europe, Brussels: European Commission (6 April 2016).

19 Asylum Information Database (AIDA) (2015/2017). Country Report: Italy (Dec 2015 and Feb 2017). https://www.asylumineurope.org/reports/country/italy, accessed 3 March 2020; Ibid., Country Report: Greece, (Nov 2015 and March 2017). https://www.asylumin europe.org/reports/country/greece, accessed 3 March 2020; see similar links for more recent statistics and reports, illustrating a general decrease in applications.

20 European Commission (2016). $\operatorname{COM}(2016)$ 270, 2016/o133 (COD). Proposal for a Regulation of the European Parliament and of the Council establishing the criteria and mechanisms for determining the Member State responsible for examining an application for international protection lodged in one of the Member States by a third-country national or a stateless person (recast). Brussels: European Commission (4 May 2016).

21 European Parliamentary Research Service (EPRS) (2019). Briefing: Reform of the Dublin system, PE 586.639, (1 March 2019). http://www.europarl.europa.eu/RegData/etudes/ BRIE/2016/586639/EPRS_BRI(2016)586639_EN.pdf, accessed 10 Aug 2019.

22 EU Observer (2020). Commission bins 'Dublin' asylum-reform proposal (20 Feb 2020), https://euobserver.com/migration/147511, accessed 3 March 2020 . 
ambitious promise to relocate 160,0oo asylum seekers from Greece and Italy. ${ }^{23}$ Also the relocation of unaccompanied minors from the Greek islands has proven difficult. ${ }^{24}$ Consequently, due to the stagnating solidarity initiatives and lack of a distribution key, frontline States are in principle responsible for the application procedure of incoming seaborne refugees. ${ }^{25}$

Accordingly, the concern of heavily pressured frontline States to bear full responsibility for refugee reception in the absence of solidarity explains their unwillingness to allow the disembarkation of rescued refugees. ${ }^{26}$ In order to address this tension, Germany, France, Malta and Italy started negotiating temporary arrangements for disembarkation after SAR operations in the Mediterranean, pending consensus on a durable system in the reform of the European asylum system. ${ }^{27}$ This negotiation resulted in a joint declaration of intent - the so-called 'Malta declaration'-signed by the aforementioned quartet in September 2019 with a view of addressing controversies over SAR, disembarkation and relocation of seaborne refugees ${ }^{28}$ (see analysis in section 3). The declaration aimed to establish a "predictable and efficient temporary solidarity mechanism" to ensure "dignified disembarkation" of rescued seaborne refugees in the central Mediterranean. ${ }^{29}$ Whereas persons eligible

23 Council Decision (EU) 2015/1601 of 22 September 2015 establishing provisional measures in the area of international protection for the benefit of Italy and Greece, oJ L 248, pp. 80-94; European Commission (2017). $\operatorname{coM(2017)~} 465$ final, Fifteenth report on relocation and resettlement, Brussels: European Commission (6 Sept 2017).

24 Investigate Europe (2020). Keeping them out: How European governments ignored minor migrants for months (10 March 2020), https://www.investigate-europe.eu/minor -migrants-keeping-them-out/, accessed 17 April 2020.

25 Dublin III Regulation, supra fn. 17.

26 This unwillingness increased due to the 'corona crisis', resulting in closure of ports. See ECRE, "Med: 150 Stranded at Sea as Malta and Italy Declare Ports 'unsafe". (10 April 2020). https://www.ecre.org/med-15o-stranded-at-sea-as-malta-and-italy-dec lare-ports-unsafe/, accessed 22 April 2020.

27 European Commission (2019). Сом(2019) 481 final, Communication from the Commission: Progress report on the Implementation of the European Agenda on Migration, Brussels (16 Oct 2019); note that Italy was inclined to negotiate once Salvini lost power in the Italian Government to a more EU-friendly establishment, The Guardian, Italy PM Conte and left-leaning coalition win vote of confidence (10 Sept 2019), https://www.theguard ian.com/world/2019/sep/10/italy-pm-conte-left-leaning-coalition-vote-of-confidence, accessed 13 Jan 2020.

28 Joint Declaration of Intent on a Controlled Emergency Procedure-Voluntary Commitments by Member States for a Predictable Temporary Solidarity Mechanism (Malta declaration) (23 Sept 2019). http://www.statewatch.org/news/2019/sep/eu-temporary -voluntary-relocation-mechanism-declaration.pdf, accessed 18 Nov 2019.

Ibid., para. 1. 
for international protection were to be relocated to another participating Member State as soon as possible within four weeks, persons ineligible had to be returned "immediately after disembarkation". ${ }^{30}$

Following signature, the European Commission endeavored to encourage broader participation to the agreement at the Home Affairs Council in October 2019, yet the fervently promoted ${ }^{31}$ solidarity pact barely obtained further support. ${ }^{32}$ After all, only Portugal, Ireland and Luxembourg were inclined to joining the 'coalition of the willing. ${ }^{33}$ At the end of March 2020, six months after its signature, the 'pilot project' expired without much attention, ${ }^{34}$ having failed to break through the unpredictable situation in the Mediterranean.

Hereinafter in section 2, the article examines how the international law of the sea relates to SAR and disembarkation in the Mediterranean, which illustrates the need for a relocation mechanism.

Legal Framework Governing SAR and Disembarkation

In the following sections relevant provisions under the international law of the sea are considered, starting from the duty to render assistance to persons in distress by virtue of the 1982 Convention on the Law of the Sea (UNCLOS). ${ }^{35}$ Although the duty to render assistance forms one of the core principles of

$30 \quad$ Ibid., para. 4 .

31 Politico, 4-country deal points to shift in EU migration policy (23 Sept 2019). https://www .politico.eu/article/leaked-document-shift-eu-migration-policy/, accessed 9 Jan 2020; ANSA, Italy's Lamorgese hails deal on sharing migrant burden (23 Sept 2019), http://www .ansa.it/english/news/politics/2019/og/23/italy-hails-deal-on-migrants_11c2ob8o-fc46 -40oo-96fe-b587c12f2do3.html, accessed 9 Jan 2020; Amnesty, Malta: Asylum-seeker disembarkation deal shows a more humane approach is possible (23 Sept 2019). https:// www.amnesty.org/en/latest/news/2019/og/malta-asylum-seeker-disembarkation-deal -shows-a-more-humane-approach-is-possible, accessed 9 Jan 2020.

32 EU Observer, EU migrant boat plan fails to get extra support (9 Oct 2019). https://euob server.com/migration/146214, accessed 18 Nov 2019; see also ЕC, сом(2019) 481 final, supra fn. 27 .

33 Politico, 4-country migration deal struggles to gain support (10 Oct 2019). https://www .politico.eu/article/4-country-migration-germany-france-italy-maltadeal-struggles-to -gain-support/, accessed 17 Jan 2020.

34 The declaration was valid from 23 September until 23 March 2020. Malta declaration, supra fn. 28 , para. 15 .

35 UN General Assembly, Convention on the Law of the Sea (10 Dec 1982), 1833 UNTS 397. Entry into force: 16 Nov 1994. 
UNCLOS, there are other international conventions that come closer to the heart of the disembarkation discussion, as will be set out.

\subsection{Render Assistance}

The obligation to provide assistance at sea reflects customary international law ${ }^{36}$ and has been codified in Article 98(1) of UNCLOS. ${ }^{37}$ It prescribes: "Every State shall require the master of a ship flying its flag, in so far as he can do so without serious danger to the ship, the crew, or the passengers (...) to render assistance to any person found at sea in danger of being lost (...)." The exercise of this general obligation must "conform to generally accepted international regulations",38 more specifically Regulation 33(1) of the 1974 International Convention for the Safety of Life At Sea (solas Convention) ${ }^{39}$ which entails the detailed requirement for the shipmaster, ${ }^{40}$ to proceed, on receipt of information from any source, to the assistance of persons in distress where reasonably possible, regardless of the nationality and status of such persons or the circumstances which caused the distress. ${ }^{41}$ The last part reflects the nondiscriminatory character of rescue, which has been reemphasized by the Council of the International Maritime Organization (IMO $)^{42}$ and the United Nations High Commissioner for Refugees (UNHCR) in the context of seaborne refugees. ${ }^{43}$ In exceptional circumstances, when proceeding to provide assis-

36 Yearbook International Law Commission (ILC) (1956), Vol. II. A/CN.4/SER.A/1956/ Add.l, United Nations Publication, 253, 281; Nordquist, M.H. et al. (1995). United Nations Convention on the Law of the Sea 1982: A Commentary. Vol. 3, Leiden: Brill, p. 171.

See elaboration of legal history in Morrison, A.P. (2016). Shipping: safety of life at sea, in: R.M. Warner and S.B. Kaye (Eds.), Routledge Handbook of Maritime Regulation and Enforcement. pp. 197-211, at 161-175. Abingdon: Routledge.

38 Art. 94(5) UnClos; see for interrelationship unClos and International Maritime Organization (IMO) conventions, LEG/MISC.8 (30 Jan 2014).

39 Imo, International Convention for the Safety of Life At Sea (1 Nov 1974), 1184 UNTS 3. Entry into force: 25 May 1980.

40 The ship's captain.

41 Annex solas Convention, Ch. v, Reg. 33(1); NB: the recipient of the obligation to rescue is the shipmaster and not the State, as also flows from other binding and soft law instruments. See Bevilacqua, G. (2019). Italy Versus NGOS: The Controversial Interpretation and Implementation of Search and Rescue Obligations in the Context of Migration at Sea. The Italian Yearbook of International Law 28(1), pp. 11-27.

$42 \mathrm{C}_{54 / 17}$ (d) (IMo Council); cited by Nordquist (1995), supra fn. 36, p. 175; the IMO is the United Nations specialized agency with responsibility for safety and security of shipping and prevention of marine and atmospheric pollution by ships.

43 Addendum to Report Executive Committee UNHCR, 36th session (7-18 Oct 1985): A/4o/12/Add.1 (GAOR, 4oth sess., Suppl. No. 12A), A/AC.96/673, 32. 
tance is impossible or unreasonable for the vessel receiving the distress call, the shipmaster must inform the appropriate SAR authority and insert in the ships $\log$ the reason for the decision. ${ }^{44}$ In that case, other requisitioned ships shall render assistance. ${ }^{45}$ Based on the foregoing, it is evident that drowning persons are to be rescued. However, it is less evident where the shipmaster should bring these people after rescue. It raises the questions what the scope is of shipmasters' and coastal States' obligations and whether a rescue operation involves the disembarkation of the rescued people at a place of safety. ${ }^{46}$ While Article 98 unCLOS does not provide a clear-cut answer, the International Convention on Maritime Search and Rescue (sar Convention) ${ }^{47}$ and SOLAS Convention-analyzed in the following — might do.

\subsection{SOLAS and SAR Amendments and Guidelines}

In the wake of the $M V$ Tampa incident in $2001^{48}$-in which a container ship recovered hundreds of refugees in the Indian Ocean, but found itself for a considerable time in an awkward position in between States reluctant to allow disembarkation at their territory-the IMO Assembly adopted a resolution which recommended reviewing measures and procedures for the treatment of rescued persons, ensuring the life of persons aboard ships is safeguarded and coastal communities should deal with such people satisfactorily. ${ }^{49}$ Accordingly, the Assembly kicked off the further development of conventions concerned with treatment of persons rescued at sea.

The IMO is an organization with the responsibility of maintaining maritime conventions $\mathrm{s}^{50}$ - a competence that stems from its constitutive instrument $^{51}$ and more in particular from other relevant international maritime conventions. ${ }^{52}$ As part of the IMO, the Maritime Safety Committee (MSC) deals

\footnotetext{
44 Annex solas Convention, Ch. v, Reg. 33(1).

45 Ibid., (2).

46 Papanicolopulu, I. (2016). The Duty to Rescue at Sea, in Peacetime and in War: A General Overview. International Review of the Red Cross 98(902), pp. 491-514, at 499.

47 IM O, International Convention on Maritime Search and Rescue (27 April 1979), 1403 UNTS. Entry into force: 22 June 1985.

48 Vadarlis v. Minister for Immigration and Multicultural Affairs and Others (Federal Court of Australia, V 900 of 2001).

49 Imo Res A.920(22), (29 Nov 2001).

50 Rothwell, D.R. et al. (2015). The Oxford Handbook of the Law of the Sea. Oxford: Oxford University Press, p. 421.

51 Art 2(b) of the United Nations, Convention on the International Maritime Organization (6 March 1948), 289 UnTs 3. Entry into force: 17 March 1958.

52 E.g. Article viII, solas Convention; Article III, SAR Convention.
} 
with safety issues at sea. For that reason, talks on the treatment of persons rescued at sea took place within the $\mathrm{MSC}^{53}$ and specialized subcommittees. ${ }^{54}$ After preliminary consideration of the Assembly's requests, gaps in the SOLAS and SAR conventions were identified concerning, inter alia, the obligations of shipmasters and States. ${ }^{55}$ Following discussions regarding these gaps, the MSC adopted amendments to the annexes of the solAs and SAR conventions, ${ }^{56}$ which were considered to have been accepted on 1 January 2006 - as no more than one third of the State Parties notified objections to the amendments ${ }^{57}$ in accordance with the so-called tacit acceptance procedure. ${ }^{58}$

In the present context, added Regulation 33 paragraph 1-1 (Chapter v) of the solas Convention (Reg. 33(1-1) SOLAS) is important, since this provision pays particular attention to the duty to permit disembarkation. ${ }^{59}$ It requires States to ensure that the shipmaster is released from all responsibility with the least deviation as possible from the ships voyage, provided that the safety of the persons rescued is not compromised. Moreover, the States responsible for search and rescue operations must take steps to ensure that survivors are

53 IMO MSC $75^{\text {th }}\left(15^{-24}\right.$ May 2002), 76th (2-13 Dec 2002) and 77th (28 May-5 June 2003) session.

54 IMO COMSAR 6th (18-22 Feb 2002), 7 th (13-17 Jan 2003) and 8th (16-20 Feb 2004) session.

55 IMO COMSAR 6/22 (8 March 20O2), paras. 8.74-8.78; the consideration of solas and SAR conventions was prioritized by the Committee, in IMO MSC 75/24 (29 May 2002), para. 22.30.

56 By virtue of art 28(b) Imo Convention, in conjunction with art VIII(b) solAs Convention / art III(2)(c) SAR Convention; the final text equals the initial draft text, which was considered a good basis for further development, as the carefully chosen wording reflected a well-balanced compromise between the stakeholders. IMO MSC 76/22/11 (27 Sept 2002); IMO COMSAR $7 / 23$ (20 Feb 2003), paras. 8.6, 8.17.

57 See Imo, Status IMO treaties (18 May 2020). http://www.imo.org/en/About/Conventions/ StatusOfConventions/Documents/StatusOfTreaties.pdf, accessed 26 May 2020; Imo Res. MSC.153(78), (20 May 2004); IMO Res. MSC.155(78), (20 May 2004); Art. VIII(b)(vi)(2)(bb) SOLAS Convention; Art. III(2)(f) SAR Convention.

$5^{8}$ Rothwell (2015), supra fn. 50, p. 421; see also for explanation of this procedure, Adede, A.O. (1977). Amendment Procedures for Conventions with Technical Annexes: The Imco Experience. Virginia Journal of International Law 17, pp. 201-216; the amendments to the conventions are globally relevant, as both conventions have been vastly ratified-SOLAS by 165 States (99.04\% world tonnage), SAR by 113 States ( $80.41 \%$ world tonnage). See IMO, Global Integrated Shipping Information System (GISIS), Status of treaties. https://gisis .imo.org/Public/ST/Treaties.aspx, accessed 1 March 2020.

59 Note that Chapter 3 of the Annex of the SAR Convention also contains paragraph 3.1.9 on disembarkation, with a similar wording and the same drafting history. In the following, this article simply refers to Reg. 33(1-1) SOLAS. 
disembarked at a place of safety (see examination of the scope of this provision in section 2.4).

Supplementary to the amendments, the MSC Resolution 167(78) sets out the Guidelines on the treatment of persons rescued at sea. The Guidelines are intended to assist States ${ }^{60}$ and shipmasters ${ }^{61}$ to "better understand their obligations under international law and provide helpful guidance concerning compliance with these obligations". ${ }^{62}$ While non-binding, ${ }^{63}$ the Guidelines are considered as reflecting a harmonized interpretation of, as well as being a necessary supplement to, the amended provisions of the SAR and SOLAS conventions. ${ }^{64}$ The guiding relevance of the Guidelines is further demonstrated by the text of Reg. 33(1-1) solAs, which (generically) refers to "guidelines of the Organization" (viz. IMO), as a factor to be taken into account during SAR and disembarkation, alongside the particular circumstances of the case.

It is important to note that Malta has reserved its position on Reg. 33(1-1) sOLAS and the corresponding Guidelines. ${ }^{65}$ Malta is therefore not bound by the duties set forth in the 2004 amendments, but merely has to abide by the SAR regime subsequent to the amendments. Hence, it is only obliged to coordinate rescue missions, without further legally binding responsibilities.

\subsection{SAR System}

While it is impossible to solely rely on shore-based rescue operations-an adequate and effective SAR regime requires shipmasters' assistance ${ }^{66}$ centralized coordination is essential for the orderly settlement of marine incidents. For this purpose, the 1979 SAR Convention was adopted, with the aim of developing a global SAR plan. ${ }^{67}$ This entails a detailed SAR arrangement which should guarantee the safety of life at sea, regardless the location of the

6o Where term (Member/flag/coastal/port) 'State' is used, it should be read to mean 'Contracting Government' to the solas Convention, or 'Party' to the SAR Convention, respectively.

61 Read: shipmasters, flying the flag of a Contracting Government or Party (see previous fn.).

62 Imo Res. MSC.167(78) (20 May 2004), para. 1.2.

63 Iмо Guidelines, appendix para. 4; see general analysis of soft law in Guzman, A.T. and Meyer, T.L. (2010). International soft law. Journal of Legal Analysis 2(1), pp. 171-225.

64 See Imo MSC 77/26 (10June 2003), para. 10.26; IMO MSC 78/26 (28 May 2004), paras. 16.4656; IMO COMSAR $7 / 23$, paras. $8.22-23$.

65 IMO MSC $78 / 26$, paras. $3.22,3.67,16.48-56$.

66 Imo Guidelines, para. 5.1.

67 Preamble, sAR Convention. 
incident. ${ }^{68}$ Hence, after the adoption of the SAR Convention, all world's oceans have been divided by IMO's MSC and subdivided by States into search and rescue regions (SRRS), in which, the State responsible for the SRR (SRR State) shall establish adequate and effective SAR services. ${ }^{69}$ SAR services are defined as the "performance of distress monitoring, communication, co-ordination and search and rescue functions", ${ }^{70}$ which require the SRR State to assign a rescue coordination center (RCC) as responsible authority. ${ }^{71}$ In the present context, especially worth mentioning are the RCCs established in the central Mediterranean by Italy, Malta and Libya. ${ }^{72}$ Each of these States have one SR R. ${ }^{73}$ Thus, notwithstanding the ability to cooperate with neighboring States ${ }^{74}$ there is to be one State primarily responsible for the coordination of SAR activities, depending on the SRR in which the recovery activity takes or took place.

\subsection{Duty-Bearers}

Reg. 33(1-1) SOLAS:

[States] shall co-ordinate and co-operate to ensure that masters of ships providing assistance by embarking onboard persons in distress at sea are released from their obligations with minimum further deviation from the ships' intended voyage, provided that releasing the master of the ship does not further endanger the safety of life at sea.

The [State] responsible for the search and rescue region in which such assistance is rendered shall exercise primary responsibility for ensuring such co-ordination and co-operation occurs, so that survivors assisted are disembarked from the assisting ship and delivered to a place of safety, taking into account the particular circumstances of the case and guidelines developed by the Organization.

In these cases the relevant [States] shall arrange for such disembarkation to be effected as soon as reasonably practicable.

68 Ibid., preamble and Ch. 2, para. 2.1.10.

$69 \quad$ Ibid., Ch. 2 para. 2.1.1; Art. 98(2) UnCLOs.

$70 \quad$ Ibid., Ch. 1, para. 1.3.3.

71 Ibid., Ch. 2, para. 2.1.2.

72 Ibid., 2.1.6; see IMO GISIS, Global SAR Plan. https://gisis.imo.org/Public/COMSAR/ Default.aspx, accessed 24 April 2020.

73 Ibid.

74 As suggested by Art. 98(2) UNCLOS. 
Three actors can be distilled from Reg. 33(1-1) solas: the shipmaster, the States and the SRR State. Their obligations regarding disembarkation are assessed in the upcoming sections. Notwithstanding the importance of incidents involving disputes over SAR, ${ }^{75}$ this article primarily focuses on duties in relation to disembarkation, as this part of maritime migration has caused the most uncertainties in the context of the central Mediterranean, which demonstrate the need for a distribution mechanism in Europe.

\subsubsection{Shipmaster: Humane Treatment after Rendering Assistance}

The most essential obligation incumbent upon the shipmaster is that of rendering assistance to people in distress at sea when he is requisitioned to do so (discussed in section 2.1). Subsequent to the initial assistance, the shipmaster must uphold the fundamental obligation to treat the embarked survivors with humanity, within the capabilities and limitations of the vessel. ${ }^{76}$ The flag State is to monitor whether the shipmaster of vessel flying its flag discharges his duties. ${ }^{77}$ This is a due diligence obligation,${ }^{78}$ which also includes the administrative control over relevant public and private vessels. ${ }^{79}$ Apart from the duties to render assistance and treat with humanity - which is, per se, 'special' within a State-oriented international legal order-Reg. 33(1-1) solAs has not established a duty for the shipmaster to disembark the survivors. Instead, "[coastal States] shall arrange for (...) disembarkation", by means of coordination and cooperation. ${ }^{80}$ To that end, shipmasters can be instructed to disembark the survivors at a determined place. Whilst this raises in principle no problems when the determined place of disembarkation is considered 'safe', it might be

75 See elaborate case studies in Gombeer, C. and Fink, M. (2018). NGOs and Search and Rescue at Sea. Maritime Safety and Security Law Journal 4; Moreno-Lax, V. et al. (2019). Between Life, Security and Rights: Framing the Interdiction of 'Boat Migrants' in the Central Mediterranean and Australia. Leiden Journal of International Law 32(4), pp. 715-740.

76 Ch. v, Reg. 33(2) solas.

77 Gammeltoft-Hansen, T. and Vedsted-Hansen, J. (2016). Human Rights and the Dark Side of Globalisation: Transnational law enforcement and migration control. Abingdon: Taylor and Francis; see generally on flag States duties, Takei, Y. (2013). Assessing flag state performance in legal terms: Clarifications of the margin of discretion. International Journal of Marine and Coastal Law 28(1), pp. 97-133.

78 UNHCR (2014) Background Paper: Mapping Disembarkation Options: Towards Strengthening Cooperation in Managing Irregular Movements by Sea, Geneva: UNHCR (4 March 2014).

79 International Court of Justice, Pulp Mills on the River Uruguay (Argentina v. Uruguay), Judgment, ICJ Reports 2010, para. 197.

8o Ch. v, Reg. 33(1-1) SOLAS. 
different when this place has a notorious record of grave human rights violations, such as Libya. ${ }^{81}$ In those cases, international refugee law and human rights law might affect the determination of the place of disembarkationprovided that these legal regimes are only binding upon States exercising jurisdiction, not non-State actors (see section 2.4.4)..$^{82}$

2.4.2 States: Discretion Due to Shared Duty and Ill-Defined Safeguards Inevitably related to the obligation of the shipmaster to render assistance at sea, is the obligation of States to release the master of his duties by disembarking the survivors. The wording of Reg. 33(1-1) SOLAS indicates the mandatory nature ("shall (...) ensure") of the coordination and cooperation by States, which eventually has to amount to the liberation of the shipmaster's responsibilities, by means of disembarkation at a place of safety. ${ }^{83}$ However, due to the establishment of a mere shared duty to allow disembarkation, States likely point at one another in their attempt to outrun the duty. ${ }^{84}$ Therefore, despite the existence of a duty to allow disembarkation upon States, "the use of the passive voice leaves unanswered the critical question of by which state rescued persons must be disembarked in the absence of agreement among affected States". 85

81 See e.g. Unsmil/ohchr, Detained and Dehumanised, Report on Human Rights Abuses against Migrants in Libya (13 Dec 2016), https://www.ohchr.org/Documents/Countries/LY/ DetainedAndDehumanised_en.pdf, accessed 26 May 2020; Amnesty International, Libya's Dark Web of Collusion: Abuses against Europe-bound Refugees and Migrants (11 Dec 2017). https://www.amnesty.org/en/documents/mde19/7561/2017/en/, accessed 26 May 2020; онснг, Abuse Behind Bars: Arbitrary and Unlawful Detention in Libya (April 2018), https://www.ohchr.org/Documents/Countries/LY/AbuseBehindBarsArbitraryUnlawful _EN.pdf, accessed 26 May 2020.

82 It has been contended that shipmasters enjoy considerable leeway in determining where to stop. See Turrini, P. (2019). Between a 'Go Back!' and a Hard (to Find) Place (of Safety): On the Rules and Standards of Disembarkation of People Rescued at Sea. The International Yearbook of International Law 28(1), pp. 29-46.

83 See Imo Guidelines, para. 3.1.

84 During the drafting process, Norway stressed this point emphatically. IMO MSC 77/10/2, (25 March 2003).

85 Guilfoyle, D. (2017). Part ViI-High Seas: Articles 86-111, in: A. Proelss (Ed.), United Nations Convention on the Law of the Sea: A Commentary. 1st edn., pp. 675-779, at 729, Hart Publishing, Oxford; see also Moreno-Lax, V. (2010). European Union. International Journal of Marine and Coastal Law 25, pp. 621-635; see for analysis co-existing responsibilities of States, De Vittor, F. and Starita, M. (2019). Distributing Responsibility between Shipmasters and the Different States Involved in SAR Disasters. The Italian Yearbook of International Law 28(1), pp. 77-95. 
Since the preliminary stage of the drafting history, the delegations stressed the "paramount importance" of a dignified treatment of rescued persons and the aim of avoiding situations in which the shipmaster would be delayed or left alone with the humanitarian responsibilities. ${ }^{86}$ Therefore, Reg. 33(1-1) SOLAS prescribes that the release cannot excessively retard the assisting ship, nor can it deteriorate the survivors' conditions. However, the said ability of States to refuse responsibility, due its shared character, could profoundly challenge the stamina of both shipmasters and survivors. This could jeopardize people in need, oftentimes already weakened by their journeys until then. Furthermore, the predicament of States' reluctance discourages the shipmaster, as the duty to rescue would inevitably be associated with the loss of time and income and would likely create an undesirable incentive to the shipmasters. ${ }^{87}$ This would mean the end of an effective humanitarian regime, since the aforementioned negative impetuses undermine the integrity and effectiveness of the SAR system.

To cater to these concerns, the drafters included the guarantee that the shipmaster's relief shall take place "with minimum further deviation from the ships' intended voyage" and disembarkation shall "be effected as soon as reasonably practicable". Whereas the objective is vivid - namely to reduce the humanitarian and monetary costs of the virtuous act - the wording leaves much discretion to States and remains open to multiple interpretations. Arguably, the 'intended voyage' concept is primarily integrated to satisfy the commercial shipping interests. ${ }^{88}$ However, in contrast, private rescue vessels have a less clear-cut 'intended voyage', as their operations are responsive in nature, anticipating the reception of sudden rescue signals. The question is whether, in the scenario such a vessel—e.g. a civil society ship—has not yet received another distress signal, that would make it defenseless towards disembarkation delays. Although the assisting vessel "should not be subject to undue delay, financial burden or other related difficulties after assisting persons at sea", 89 the wording 'should' is hortatory and leaves room for discretion. During the drafting

86 IMO COMSAR $6 / 22$, para. 8.73 .

87 Ibid., para. 8.68; see for significant role of financial incentives, Davies, M. (2003). Obligations and implications for ships encountering persons in need of assistance at sea, Pacific Rim Law and Policy Journal 12, pp. 109-143, at 128-133; see also The British Institute of International and Comparative Law, Maritime Search and Rescue: Responsibilities and Implications for Private Vessels, https://www.biicl.org/projects/maritime-search-and -rescue-responsibilities-and-implications-for-private-vessels, accessed 15 April 2020.

88 See previous fn.

89 Imo Guidelines, para. 6.3. 
process, formal attempts have been made to include safeguards to counter these concerns, ${ }^{90}$ yet the proposal guaranteeing disembarkation at the nearest port or next port of call could not collect a majority in favor. ${ }^{91}$

Alike the shared duty to allow disembarkation, the ill-defined 'place of safety' concept also leaves uncertainty. ${ }^{92}$ The lack of definition in the solas and SAR conventions is only partly addressed by the Guidelines, which vaguely define the concept as "a place where the survivors' safety of life is no longer threatened and where their basic human needs (such as food, shelter and medical needs) can be met". ${ }^{93}$ The Guidelines leave us in the dark whether to interpret this concept broadly or restrictively. Whereas it has been argued in literature that the international refugee law principle of non-refoulement (discussed in section 2.4.4) defines the meaning of a place of safety, ${ }^{94}$ others have rejected this broad integration..$^{95}$ Lastly, the Guidelines seem to convey a contradictory message. While "[i]t is a location where the rescue operation is considered to terminate", ${ }^{96}$ which is presumably on land, the assisting vessel (although discouraged), or another vessel or facility at sea, could serve as a place of safety, provided that this is only temporary in nature. ${ }^{97}$

\subsubsection{SRR State: Residual Obligation?}

Since the shared obligation to allow disembarkation does not determine responsibility between coastal States, the question is whether the SRR State has a residual obligation to allow survivors on its land, when other States have not provided for an alternative place of safety. By virtue of Reg. 33(1-1) SOLAS, the SRR State has an obligation to "exercise primary responsibility" in order to assure coordination and cooperation of SAR and disembarkation.

\footnotetext{
90 IMO MSC 77/10/2 (25 March 2003).

91 IMO MSC $77 / 26$, para. 10.36 .

92 See Ratcovich, M. (2015). The Concept of 'Place of Safety': Yet Another Self-Contained Maritime Rule or a Sustainable Solution to the Ever Controversial Question of Where to Disembark Migrants Rescued at Sea?, Australia YBIL 33(1), pp. 81-129, at 125-126.

93 Imo Guidelines, para. 6.12.

94 Ratcovich (2015), supra fn. 92; Ratcovich, M. (2019). International Law and the Rescue of Refugees at Sea, Doctoral dissertation, Department of Law, Stockholm University, Stockholm, pp. 211-282.

95 Billing, F. (2019). Delivering Refugees and Migrants to a 'Place of Safety' Following Rescue by States at Sea, Maritime Safety and Security Law Journal 6.

96 Imo Guidelines.

$97 \quad$ Ibid., paras. 6.13-14.
} 
The interpretation of this duty has been debated in literature. ${ }^{98}$ On the one hand, some scholars contended that Reg. 33(1-1) solas does not provide for a legal basis..$^{99}$ In their view, which is founded on a textual interpretation, the provision merely confers primary responsibility on the SRR State-not exclusive, absolute or final—and this "responsibility for ensuring (...) co-ordination and co-operation occurs" is only an obligation of conduct, not of result.100 On the other hand, it has been argued that Reg. 33(1-1) solas prescribes a more exclusive and compelling responsibility. ${ }^{101}$ This claim derives from the expressed intentions of the drafters ${ }^{102}$ and the Guidelines, which establish that "the responsibility to provide a place of safety, or to ensure that a place of safety is provided, falls on the Government responsible for the SAR region in which the survivors were recovered". ${ }^{103}$ This explanation was confirmed in the non-binding 'Principles relating to administrative procedures for disembarking persons rescued at sea', adopted in 2009 by IMO's Facilitation Committee (FAL). ${ }^{104}$ In the end, the nature of the responsibility to ensure disembarkation is contentious and remains open for multiple interpretations. ${ }^{105}$

98 See e.g. Guilfoyle (2017), supra fn. 85, pp. 726-727; Papanicolopulu (2016), supra fn. 46; Barnes, R. (2004). Refugee Law at Sea, International and Comparative Law Quarterly 53(1), pp. 47-77; Coppens, J. and Somers, E. (2010). Towards New Rules on Disembarkation of Persons Rescued at Sea?, International Journal of Marine and Coastal Law, 25(3), pp. 377-403; see also fundamental discussion between delegations in drafting history, IMO MSC $78 / 26$, paras. $3.63-67,3.72-75$.

99 Guilfoyle (2017), supra fn. 85, p. 729; Papastavridis, E. (2013). The Interception of Vessels on the High Seas, Contemporary Challenges to the Legal Order of the Oceans. Oxford: Hart Publishing, p. 299; UNHCR, Background Paper, supra fn. 78.

100 Ch. v, Reg. 33(1-1) solas (emphasis added); Guilfoyle (2017), supra fn. 85, p. 729.

101 Trevisanut, S. (2017). Search and Rescue Operations at Sea, in: A. Nollkaemper et al. (Eds.), The Practice of Shared Responsibility in International Law. Vol. 3, pp. 426-45o, at 433, Cambridge University Press, Cambridge.

102 See Imo Res. MSC.153(78), preambular para. 'REALIZING FURTHER'.

103 IMo Guidelines, para. 2.5.

104 IMO FAL, Principles relating to administrative procedures for disembarking persons rescued at sea, FAL.3/ Circ.194 (22 Jan 2009), principle 3.

105 Interestingly, the potential of Art. 10 of the Regulation (EU) 656/2014 ('establishing rules for the surveillance of the external sea borders in the context of operational cooperation coordinated by the European Agency for the Management of Operational Cooperation at the External Borders of the Member States of the European Union') on disembarkation has been posited by scholars. See Guilfoyle (2017), supra fn. 85; Neri, K. (2019). The Missing Obligation to Disembark Persons Rescued at Sea, The Italian Yearbook of International Law 28(1), pp. 47-62, at 56-61. However, similar to Reg. 33(1-1) solas, coastal States have leeway under this provision to delay disembarkation, as it replicates the soft language of the solas convention ("as soon as reasonably practicable"). Moreover, private vessels 


\subsubsection{Security Powers vs. Humanitarian Obligations}

Following the assessment of duties in the previous sections, one may conclude that the legal regime of SAR and disembarkation leaves many uncertainties, despite the adoption of the 2004 amendments and the soft law guidance, indeed intended to create legal clarity. The cumulation of States' shared obligation to allow disembarkation, the vaguely defined safeguard concepts, and the contentious nature of the SRR State's responsibility, allow coastal States to implement their duties and responsibilities in various ways. It risks a restrictive implementation of maritime safety, in the light of security considerations aimed to protect national borders. Indeed, coastal States enjoy enforcement powers in the territorial sea, contiguous zone and the high seas, to prevent human smuggling or activities at odds with their immigration laws. ${ }^{106}$ In principle, the passage of rescue ships towards ports can be blocked, and refugee vessels can be boarded, searched and (possibly) seized by coastal States. ${ }^{107}$ Yet, the security considerations cannot be seen in isolation: States have to perform their treaty obligations in 'good faith' (viz. the principle of pacta sunt servanda $)^{108}$ and must take into account other relevant applicable rules of international law. ${ }^{109}$ Hence, it is contended that humanitarian duties apply in the maritime context. ${ }^{110}$ In this light, the security powers are to be balanced against the rights' perspective of individuals trying to cross the Mediterranean

and government vessels operating outside the scope of FRONTEX - conducting the vast majority of rescue operations, according to statistics of the Italian Coast Guard (see https://www.guardiacostiera.gov.it/attivita/Pages/Ricerca.aspx, accessed 19 Aug 2020)— are precluded from the applicability of Art. 10. The practical relevance of this provision is therefore contestable.

106 Arts. 19(2)(g), 25 UNCLOS in territorial sea; Art. 33(1) UNCLOS in contiguous zone; Arts. 92, 110 UnClOS on high seas; see furthermore Art. 8(7) Protocol against the Smuggling of Migrants by Land, Sea and Air, supplementing the United Nations Convention against Transnational Organized Crime (adopted 15 Nov 20oo, entered into force 28 Jan 2004), 2241 UNTS 507 (Smuggling Protocol). For commentary UNCLOS articles, see Proelss, A. (Ed.) (2017). United Nations Convention on the Law of the Sea: A Commentary, Oxford: Hart Publishing.

107 Barnes, R. (2010). The International Law of the Sea and Migration Control, in: B. Ryan and V. Mitsilegas (Eds.), Extraterritorial Immigration Control. pp. 100-146, Leiden: Brill.

108 Art. 26 of the United Nations, Vienna Convention on the Law of Treaties (VCLT) (23 May 1969), 1155 UNTS 331. Entry into force: 27 Jan 1980.

109 Art. 31(3)(c) VCLT; Arts. 2(3), 87(1) UNCLOS.

110 See e.g. Oxman, B.H. (1997). Human Rights and the United Nations Convention on the Law of the Sea, in: J. Charney et al. (Eds.), Politics, Values and Functions, International Law in the 21st Century, Essays in Honor of Professor Louis Henkin. p. 377, Leiden: Martinus Nijhoff; Vukas, B. (2004). Droit de la mer et droits de l'homme, in: Vukas, B. (Ed.), The law of the sea: selected writings. Vol. 45, pp. 71-8o, Leiden: Nijhoff Publishers; Cacciaguidi-Fahy, S. 
to seek protection. States' obligation to protect these rights should be integrated when considering disembarkation at a place of safety. ${ }^{111}$ This consideration is therefore not merely a matter of policy choices driven by political agendas, but indeed also requires compliance with relevant fundamental international norms.

Apart from the protections guaranteed in the SAR regime, seaborne refugees can claim rights by virtue of several international and regional human rights treaties. ${ }^{12}$ Relevant in relation to disembarkation are, inter alia, the right to life, the principle of non-refoulement, the right to leave to seek asylum, the prohibition of collective expulsion, the principle of non-discrimination, the right to liberty, the right to family life and the best interests of the child. ${ }^{113}$ One might argue that the right to life ${ }^{114}$ draws a humanitarian limit during a disembarkation standoff in which human health deteriorates, thus likely informs the urgency for disembarkation. Yet, based on recent interim measure decisions by the ECtHR concerning such situations, States exercising jurisdiction still have the ability to postpone their obligation to allow disembarkation and maintain the status quo, as long as the conditions aboard do not amount to a violation of the right to life. ${ }^{115}$ Arguably, during such standoffs, the principle of non-refoulement neither triggers a positive obligation for one particular State to allow disembarkation. This fundamental principle prohibits States exercising jurisdiction from expelling or returning a refugee to the frontiers of territories where his or her life or freedom would be threatened. ${ }^{116}$ Yet, the mere denial

(2007). The law of the sea and human rights, Sri Lanka Journal of International Law 19, pp. 85-107.

111 See for 'systemic integration' of humanitarian duties in maritime context, Moreno-Lax et al. (2019), supra fn. 75; see also Moreno-Lax, V. (2014). Systematising Systemic Integration: 'War Refugees', Regime Relations, and a Proposal for a Cumulative Approach to International Commitments.Journal of International Criminal Justice 12(5), pp. 907-929.

112 See UN General Assembly, International Covenant on Civil and Political Rights (ICCPR) (16 Dec 1966), 99 UNTS 171. Entry into force: 23 March 1976; UN General Assembly, Convention against Torture (CAT) (10 December 1984), 1465 UNTs 85; Council of Europe, European Convention for the Protection of Human Rights and Fundamental Freedoms, as amended by Protocols Nos. 11 and 14 (ECHR), (4 Nov 1950), ETS 5. Entry into force: 3 Sept 1953 .

113 See elaborate analysis in Ratcovich (2019), supra fn. 94; see also Coppens, J. (2013). Migrants at sea: a legal analysis of a maritime safety and security problem, Doctoral Dissertation, Faculty of Law, Ghent: Ghent University.

114 Art. 6 ICCPR; Art. 2 ECHR.

115 See ECtHR interim measures, 043 (2019) 29.01.2019, and 240 (2019) 25.06.2019.

116 See art 33(1) of the UN General Assembly, Convention Relating to the Status of Refugees (Refugee Convention), (28 July 1951), 189 UNTS 137. Entry into force: 22 April 1954; Art. 3; 
of entry of rescue ships to the territorial waters or internal waters (including return to the high seas) does not automatically result in the return of individuals to a place where their lives would be endangered. The rejection to allow disembarkation must therefore be differentiated from the physical return to a place of persecution. ${ }^{117}$ Similarly, it is very controversial to deduce an ancillary right of entry from the right to leave to seek asylum, ${ }^{118}$ which arguably entitles a person claiming to be a refugee, to have that claim assessed. ${ }^{119}$ It is contended that only when the issuance of an entry visa is the last resort to avoid torture or other forms of ill-treatment, the host State has a positive obligation to grant entry. 120

What has furthermore been debated in the recent years is the applicability ratione loci of the principle of non-refoulement in the context of migration by sea (which is also relevant to other human rights). ${ }^{21}$ Whereas some national jurisdictions have interpreted the matter restrictively, ${ }^{122}$ the prevailing stance among courts and monitoring bodies is that non-refoulement applies beyond national boundaries—including on the high seas. ${ }^{123}$ The relevant standard

Art 19(2) of the European Union, Charter of Fundamental Rights of the European Union (CFREU), (26 October 2012), 2012/C 326/o2. Legally binding since 1 Dec 2009; see "obligation not to expel” in Hirsi Jamaa v. Italy, App. No. 27765/o9 (ECtHR 23 Feb 2012), para. 114 .

117 Barnes (2004), supra fn. 98, p. 70; Goodwin-Gill, G.S. (1996). The Refugee in International Law. Oxford: Clarendon Press, 2nd ed., p. 166.

118 Yet, see for analogical counterargument, Moreno-Lax, V. (2017). Accessing Asylum in Europe: Extraterritorial Border Controls and Refugee Rights under EU Law, Oxford: Oxford University Press, pp. 389-9o; see for general discussion of this so called 'right to flee', Orchard, P. (2014). A right to flee: Refugees, States, and the Construction of International Cooperation, Cambridge: Cambridge University Press.

119 Moreno-Lax (2017), ibid:; Papastavridis (2013), supra fn. 99, p. 217.

120 Noll, G. (2005). Seeking Asylum at Embassies: A Right to Entry under International Law?, International Journal of Refugee Law 17(3), pp. 542-573.

121 See discussion in Klein, N. (2014). Assessing Australia's Push Back the Boats Policy under International Law: Legality and Accountability for Maritime Interceptions of Irregular Migrants, Melbourne Journal of International Law 15, pp. 414-443; Ghezelbash, D. et al. (201). Securitization of Search and Rescue at Sea: The Response to Boat Migration in the Mediterranean and Offshore Australia, ICLQ 67(2), pp. 315-351; Moreno-Lax, V. (2017). The Interdiction of Asylum Seekers at Sea: Law and (Mal)practice in Europe and Australia, Kaldor Centre Policy Brief 4, Sydney: unsw.

122 See e.g. Sale v Haitian Centers Council Inc (1993) USSC 89; 509 US 155, paras. 158-9, 181-2.

123 HirsiJamaav. Italy, supra fn. 116, paras. 76-82; The Haitian Centre for Human Rightsv United States (Inter-American Commission of Human Rights, Report No 51/96, Case No 10.675, 13 March 1997); Executive Committee of the High Commissioner's Programme, Interception of Asylum Seekers and Refugees: The International Framework and Recommendations 
for the ICCPR, CAT and ECHR to determine extraterritorial jurisdiction is whether the State exercises 'effective control' over an area or person abroad. ${ }^{124}$ While extraterritoriality has been concluded in cases concerning State vessel pushback practices, ${ }^{125}$ the question arises how the non-refoulement principle relates to rescue operations on the high seas involving third parties, coordinated by the RCC of the SRR State. For instance, it is open to question whether (non-physical) instructions by the Italian RCc, telling the Libyan Coast Guard to intercept refugee vessels and have the refugees returned to Libya, amount to effective control on part of the RCC (attributable to the SRR State). Whereas scholars have argued such instructions are merely non-binding "requests for cooperation" by virtue of the international law of the sea, ${ }^{126}$ the ECtHR determines State obligations under the Convention on the basis of the effective control doctrine. The Court has implicitly considered the Convention applicable in a case on the high seas where government notifications were sent to the shipmaster and a warship was placed in the vicinity, ${ }^{127}$ yet the real test case, concerning an instructed pullback by the Libyan Coast Guard, is at the time of writing pending before the ECtHR. ${ }^{128}$

\section{$3 \quad$ Malta Declaration: A Solution After All?}

The legal regime of SAR and disembarkation under international law of the sea is based on the premise of a balanced compromise text, which has taken duly note of the competing interests of the stakeholders. There are concerns of lifesaving, preservation of the integrity and effectiveness of SAR services, as well as relieving shipmasters of obligations after assisting persons-indicated by the drafters as 'SAR Priorities.' ${ }^{129}$ Yet, as a result of uncertainties emanating

for a Comprehensive Approach, UN Doc EC/5o/SC/CRP.17 (9June 200o), 4 [23]; Executive Committee of the High Commissioner's Programme, Interception of Asylum Seekers and Refugees: The International Framework and Recommendations for a Comprehensive Approach, UN Doc EC/5o/SC/CRP.17 (9 June 2000), 4 [23]; European Roma Rights Centre $v$ Immigration Officer at Prague Airport [2003] EWCA Civ 666 (20 May 2003) [34]; [2005] 2 AC 1.

124 See elaboration in Moreno-Lax (2017), supra fn. 118, Ch. 5 .

125 See supra fn. 123.

126 Gombeer and Fink (2018), supra fn. 75, p. 17.

127 Women on Waves et al v. Portugal, App. No. 31276/o5 (ECtHR, CM/ResDH(2011)145) (judgment of 3 Feb 2009, final on 3 May 2009).

128 S.S. et al v. Italy, App. No. 2166o/18 (ECtHR).

129 See Imo Guidelines, para. 3.1. 
from the legal framework, States seize the opportunity to fill up the lacunas with security measures. Whereas the analysis in the last section has shown that the humanitarian duties limit the securitization of maritime migration, States remain largely in charge of disembarkation on their territories. States' unwillingness to allow disembarkation causes doubt and potentially frustrates the implementation of the aforementioned SAR priorities.

Since States' reluctance to cooperate can be construed by the fact that disembarkation of refugees triggers the politically sensitive obligations of refugee reception (see introduction), the establishment of an effective and predictable underlying relocation scheme would tackle these problems at the roots. It would remove the issues from the inherently perilous sea. To that end, the highly anticipated Malta declaration, signed by Germany, France, Malta and Italy, intended to provide for a more predictable and efficient temporary solidarity mechanism. ${ }^{130}$ The declaration recognized the humanitarian concern of SAR, as it aimed to ensure dignified disembarkation for those rescued at sea. ${ }^{131}$ However, despite its well-intended objectives, the declaration indeed fell short in providing an effective and foreseeable solution for rescued refugees in the Mediterranean.

The content of the declaration exhibited shortcomings with regards to various stages after rescue of refugees at sea. Firstly, the provisions concerning disembarkation lacked clarity and safeguards. Disembarkation were to take place "on a rotation basis", grounded upon a shortlist of EU safe ports ${ }^{132}$ —arguably to increase fairness towards frontline States. Yet, the rotational scheme failed to acknowledge that if an effective underlying relocation scheme exists, the matter of disembarkation becomes less relevant with regards to a fair distribution among States. Even if the matter is relevant, for instance in case of limited local reception capacities, ${ }^{133}$ the declaration failed to provide for an objective formula to determine the breaking point of these capacities. Also, instead of automatically pointing out another place of safety, disembarkation was in such circumstances dependent upon a voluntary proposal by an alternative port/ State. ${ }^{134}$ After all, the vague provision on disembarkation obscured the responsibility question, hence further undermined the predictability of the SAR and

\footnotetext{
130 Malta declaration, supra fn. 28 , para. 1.

131 Ibid., para. 1.

132 Times of Malta, Minister reveals details of draft migration deal (27 Sept 2019). https:// timesofmalta.com/articles/view/minister-reveals-details-of-draft-migration-deal.738211, accessed 10 Feb 2020.

133 Malta declaration, supra fn. 28, para. 1.

134 Ibid.
} 
disembarkation regime and left room for stand-offs, instead of rendering the proclaimed "predictable and efficient" mechanism "to ensure dignified disembarkation". ${ }^{135}$ Furthermore, the principle of non-refoulement was absent in the Malta declaration. Worse still, by asserting flag States' duty to disembark at their territory after rescue was conducted by a state-owned vessel, ${ }^{136}$ the declaration vindicated the competence of the Libyan Coast Guard to pullback rescued refugees. In the same vein, the declaration prescribed that NGOs should refrain from obstructing the Libyan Coast Guard ${ }^{137}$ and the latter's capacities were to be enhanced. ${ }^{138}$ Accordingly, European States seem to be willing to intensify their relationship with Libya in their fight against irregular migration, ${ }^{139}$ despite the fact that this tendency increases the risk of refoulement, given widespread evidence of unlawful conduct of Libyan authorities in relation to pullback practices. ${ }^{140}$

Secondly, beyond the disembarkation stage, the declaration lacked clarity and transparency with regards to its implications to relocation, asylum procedure and return. The declaration asserted to provide for a 'fast track system' of relocation based on 'pre-declared pledges' before disembarkation. ${ }^{141}$ While the temporal limits for relocation were clearly given (viz. as soon as possible within 4 weeks of disembarkation), ${ }^{142}$ further specifics of the system were puzzling, leaving space for multiple interpretations. Note in this regard that

\footnotetext{
135 Ibid.

136 Ibid.

137 Ibid., para. 9 .

138 Ibid., para. 14.

139 Note in this regard Malta declaration, ibid., para. 14, which demonstrates the intention to start discussing the possibilities of outsourcing disembarkation to Mediterranean third countries. This reminisces the highly criticized 2018 proposals of regional disembarkation platforms across EU's borders. See Fantinato, M. (2019). EU Regional Disembarkation Arrangements in the Mediterranean: Between the Outsourcing of Search and Rescue Services and the Externalisation of Sea Border Management, The Italian Yearbook of International Law 28(1), pp. 63-76; see also Abderrahim, T. (2019). Pushing the Boundaries: How to Create More Effective Migration Cooperation Across the Mediterranean, ECFR Policy Brief, London: European Council on Foreign Relations.

140 See Communication to the Office of the Prosecutor of the International Criminal Court Pursuant to Article 15 of the Rome Statute. EU Migration Policies in the Central Mediterranean and Libya (2014-2019), http://www.statewatch.org/news/2019/jun/eu-icccase-EU-Migration-Policies.pdf, accessed 10 Feb 202O; see also UNHCR, UNHCR Position on Returns to Libya-Update II (Sept 2018), https://www.refworld.org/docid/5b8do2314 .html, accessed 1o Feb 2020.
}

141 Malta declaration, supra fn. 28, para. 4.

142 Ibid., paras. 2, 5. 
'pre-declared pledges' reads like the ad hoc relocation schemes following disembarkation between several EU Member States in the recent years. ${ }^{143}$ This piecemeal ship-by-ship approach demonstrated a very welcome token of solidarity, yet fell short in providing fair support to frontline States, swift disembarkation, and compliance with asylum standards. ${ }^{144}$ For the Malta declaration, similar concerns were looming. For instance, it is uncertain whether individual circumstances, such as family relations and vulnerabilities, were considered in the relocation process. ${ }^{145}$ Furthermore, there were concerns that the declaration encouraged pre-selection practices among the participating States in line with their political preferences, ${ }^{146}$ which are at odds with the nondiscrimination principle in international refugee law and human rights law. ${ }^{147}$ Moreover, it remains questionable whether the declaration provided sufficient safeguards against unsafe returns, as people could be returned "immediately after disembarkation", provided that they have gone through minimal security and medical screening. ${ }^{48}$

Apart from the content, the nature of the declaration also indicated that this instrument could not have been regarded as a reliable solution. The declaration lacked precision in many aspects (see above) and was a mere statement of intention - as suggested by its title 'Joint Declaration of Intent'. The absence of the intention to create legal rights and obligations upon the signatories rendered the agreement non-binding. ${ }^{49}$ The agreement had a voluntary character, both externally and internally. From an external perspective, reluctant EU Member States were not obliged to join the solidarity pact. From an internal perspective, States committed to the declaration could have freely shaped the

143 E.g. Al Jazeera, Spain, Portugal to accept more rejected Aquarius refugees (14 Aug 2018), http://bit.ly/2JBg7QQ, accessed 6 Feb 2020; The Guardian, Italy's Salvini refuses to back EU deal on rescue ship migrants (9 Jan 2019), http://bit.ly/2H6giTL, accessed 6 Feb 202O; see also preambular paragraph vi of the Malta declaration, supra fn. 28.

144 ECRE (2019). Relying on relocation. ECRE's proposal for a predictable and fair relocation arrangement following disembarkation, Policy paper 6, Brussels: ECRE.

145 See Common position on the EU Justice and Home Affairs (JHA) Council of Oct 7-8, 2019, updated version, https://sea-watch.org/wp-content/uploads/2019/10/PositionPaper_JHA. pdf, accessed 10 Feb 2020 .

146 Carrera, S. and Cortinovis, R. (2019). The Malta Declaration on SAR and Relocation: A Predictable EU Solidarity Mechanism?, CEPS Policy Insight 14-2019, p. 4.

147 Article 3 Refugee Convention; Article 14 ECHR; Article 21 CFREU.

148 Malta declaration, supra fn. 28, para. 4.

149 Damrosch, L.F. and Murphy, S.D. (2014). International Law: Cases and Materials. American Casebook Series, 6th edn, Minnesota: West Academic Publishing, St. Paul, p. 264; note also that the declaration cannot be seen as EU legal act. 
level of their commitment and may have stepped out at any time. ${ }^{150}$ This ad $h o c$, emergency driven, partial solidarity was likely to result in a situation of responsibility cherry-picking or 'solidarity à la carte,, ${ }^{151}$ contrary to the unified understanding of solidarity in the EU Treaty ${ }^{152}$-an interpretation affirmed by the Court of Justice EU. ${ }^{153}$ Moreover, the declaration did not constitute a durable solution given its temporary character. The 'pilot project', which was only valid for six months, ${ }^{154}$ could have been renewed upon agreement, but could also have been suspended when the number of relocated persons had significantly increased. ${ }^{155}$

The context of the declaration corroborates the conclusion that the agreement was not the answer. Eventually, the instrument only obtained support from three additional EU Member States, despite repetitive attempts by the European Commission to increase leverage. ${ }^{156}$ The lack of appeal was a real loss for the initiative, since broader support was needed in order to utilize the EU reception capacities to its full potential, so to enhance the predictability of the process following rescue at sea. The absence of substantial support by other frontline States can be partly construed by the limited territorial scope of the declaration, since it merely covered rescue operations and resources regarding the central Mediterranean, as opposed to alternative corridors. ${ }^{157}$ Other EU Member States, for instance the Netherlands, have also shied away from the solidarity mechanism, because they claimed the deal failed to provide a structural answer to the problems in the Mediterranean, and instead preferred awaiting

150 Note e.g. the emergency clause explained by the Maltese Minister of Home Affairs. Times of Malta, Minister reveals details of draft migration deal (27 Sept 2019), supra fn. 132 .

151 Gauci, J.P. and Karageorgiou, E. (1019). Solidarity 'A La Carte': The EU's Response to Boat Migration, Opinio Juris, (9 Aug 2019), https://opiniojuris.org/2019/o8/og/solidarity -a-la-carte-the-eus-response-to-boat-migration/, accessed 11 Feb 2020; Carrera and Cortinovis (2019), supra fn. 146, pp. 6-7.

152 Ibid.; Art. 80 of the European Union, Treaty on the Functioning of the European Union (Consolidated Version) (TFEU), (13 Dec 2007), 2008/C 115/o1. Entry into force: 1 Dec 2009.

153 Court of Justice of the European Union, Judgment in Joined Cases C-643/15 and C-647/15 Slovakia and Hungary $v$ Council, Luxembourg, 6 Sept 2017.

154 From 23 Sept until 23 March 2020.

155 Malta declaration, supra fn. 28, para. 15 .

156 See supra fn. 32.

157 Politico, It's not all about Italy! 3 EU countries call for change to migration focus (8 Oct 2019), https://www.politico.eu/article/migrant-route-eastern-mediterranean -sea-not-all-about-italy-3-eu-countries-call-for-change-to-migration-focus/, accessed 6 Feb $202 \mathrm{O}$. 
the integral reform of the Dublin system. ${ }^{158}$ This argument is debatable. One may argue that the imminent and humanitarian nature of the issue demands a quick response and cannot wait for the endless negotiations towards a reform of the European asylum acquis. ${ }^{159}$ Furthermore, migration issues are complex by nature and require a step-by-step approach - this declaration created by a coalition of the willing could have been the first step and was therefore not without value. ${ }^{160}$ On the other hand, one may contend that the complicated problem of disembarkation and relocation of seaborne refugees necessitates a unified responsibility-sharing mechanism in order to increase effectiveness and predictability, which is essential in order to tackle the uncertainty raised by the legal regime of disembarkation and to create resilience against large migration influxes. Particularly in the long term, partial, conditional or temporal forms of solidarity do not suffice and might be seen as a step backwards towards intergovernmentalism—away from EU's foundation. ${ }^{161}$

\section{$4 \quad$ Concluding Remarks}

The three stages of the 'Mediterranean crisis'-SAR, disembarkation, relocation-are intertwined and cannot be seen in isolation. An effective search and rescue by shipmasters, informed by humanitarian considerations, is dependent upon the security of prompt disembarkation. Swift disembarkation, on its part, is at times of heavily pressured frontline States inevitably linked to the guarantee of subsequent relocation. Practice reveals that, in the absence of the latter warrant, the smooth functioning of the three-stage chain could be endangered, which often comes at a high price. Indeed, it discloses a rather fundamental call for responsibility-sharing, underscoring the importance of distributive justice in the organization of collective responsibility. After the latest well-intended yet underwhelming initiative of voluntarism,

${ }_{15} 8 N R C$, Nederland doet niet mee aan akkoord over migratie Middellandse Zee (8 Oct 2019), https://www.nrc.nl/nieuws/2019/10/o8/nederland-doet-niet-mee-aan-akkoord-overmigratie-middellandse-zee-a3976o62, accessed 12 Feb 2020.

159 See ECRE, (2019). Weekly Editorial: Disembarkation-Are We Nearly There Yet? (11 Oct 2019), Brussels: ECRE, https://www.ecre.org/disembarkation-are-we-nearly-there -yet/, accessed, 12 Feb 2020.

160 Ibid.

161 Carrera, S. and Cortinovis, R. (2019). Search and rescue, disembarkation and relocation arrangements in the Mediterranean. Sailing Away from Responsibility?, CEPS Paper in Liberty and Security in Europe No. 2019-10, Brussels: CEPS. 
it is to be hoped that the EU-27 can agree on a new system of responsibility, which creates legally binding commitments upon Member States and places greater emphasis on the interest of sustaining the principle of solidarity. Besides increasing values of fraternité and communauté in the Union, this would be pivotal for taking onboard the humanitarian issue of disembarkation in the Mediterranean Sea.

\section{Acknowledgements}

The author is very grateful to Prof. Marjoleine Y.A. Zieck for her helpful comments and critical reading. Any errors or omissions remain his own. 